\title{
9. Towards a New Language: Strindberg's Break with Naturalism
}

In Strindbergs bildspråk (Strindberg's Imagery), which still remains, even after thirty-five years, the most sensitive and thorough study of Strindberg's language yet published, Karl-Åke Kärnell quotes from a critical commentary on Mallarmé: 'Ce goût des analogies, cette obsession même, était le trait fondamental du caractère de l'homme... Tout pour lui était métaphore, comparaison, image. L'analogie était la façon la plus simple de comprendre... Cette obsession a dû être pénible à la fin. Elle le prit corps et âme; elle domina dans son travail et dans ses loisirs.' Kärnell adds: 'This is a characterization that could be transferred almost word for word to the Strindberg of the 1890s... In fact, of contemporary Swedish writers there can really have been no one whose thoughts were so clearly and unequivocally formulated in a "symbolist" manner as were Strindberg's. ${ }^{1}$

In later years Strindberg appeared himself to have little time for symbolism. Characteristically remarking upon what he took to be the way in which the symbolists employed language to conceal rather than to reveal, to mask rather than, as he was concerned to do throughout his career, to unmask, he recalled in his Speeches to the Swedish People (Tal till Svenska Nationen) that 'It was an obscure language, which abandoned all content and sought to work solely through the resources of language, awakening perceptions of colour and sound, in short to conceal what should be seen, hide light under a bushel and operate with dark rays of light' [SV 68, 88]. But there is no doubt that in any account of the remarkable shifting his own work from the naturalism of the 1880 s to what, in Legends (1898), he termed the 'supranaturalism' of his postInferno writing, symbolism has a part to play as one element among many in the remarkable ferment of ideas to which he committed himself between his departure from Sweden for Berlin in September 1892 and the publication of Inferno in 1897 and To Damascus I-II in 1898. As is well known, during this period in which he negotiated a passage from the nineteenth-century structures of feeling of his principal naturalist works to the full-blown modernism of such later texts as A Dream Play (1901) or the stream-of-consciousness novella The Roofing Feast (Taklagsöl, 1906), Strindberg wrote almost no imaginative 
literature but abandoned himself to a variety of other discourses - scientific, alchemical, occult - in which it is notoriously difficult to discern a unifying pattern. And yet, to simplify: what eventually enabled him to resume his career as a dramatist, and in so doing to establish a basis for theatrical modernism, was the development of a new language that he forged during this period, much of it spent in Paris where he clearly played the field of the available journals and publishing houses, including the symbolist La Plume, with considerable promiscuity.

In what follows I wish briefly to note two of the major routes by way of which Strindberg effected this return to the theatre, and to consider them in the context of French symbolism. Although, soon after arriving in Paris, he briefly sought literary notoriety in the then fashionable detraqué style with the prose meditation 'Sensations détraquées' (Deranged Impressions, 1894), which Strindberg told the painter Richard Bergh was regarded by his drinking companions at the Café Napolitain as 'new, extraordinaire but mad' $[\mathrm{X}, 35 ; 2,519]$, and then rapidly went on to discover common ground with the symbolists in their mutual interest in alchemy (like Mallarmé, he was preoccupied with what the latter described, in a letter to Henri Cazalis, as 'L'CEuvre, le Grand Oeuvre, comme disaient les alchimistes, nos ancêtres'), ${ }^{2}$ he did not, it is true, seek to emulate the latter and 'describe not the object itself, but the effect it produces.' Indeed, his imagination was always too concrete for such an approach. But few more than Strindberg have been so haunted by what Mallarmé termed 'the demon of analogy', and his later achievement as a dramatist is inconceivable without the crucial shift in his attitude to the domain of language that he essayed during the mid-1890s, a shift that was achieved, in part at least, by his encounter with one of the principal inspirations of symbolism, Swedenborg, who, as Baudelaire famously commented, in his essay on Victor Hugo, 'has already taught us that everything, form, movement, number, colour, perfume, in the spiritual as in the natural, is significant, reciprocal, converse, correspondent... Thus, what is a poet (I take the word in its widest sense) if not a translator, a decipherer?' ${ }^{4}$

First, however, a brief comment on Strindberg's naturalism. In his early years, and still more intensively during the 1880s, Strindberg had frequently expressed misgivings about the pleasure to be derived from works of art, and in particular from imaginative literature, or fiction, which at the time he often regarded as essentially duplicitous, unlike his touchstone, nature, which for the moment at least he considered artless. His youthful Pietism, which was first compounded with a highly personal reading of Kierkegaard, for whom the ethical is elevated above the aesthetic, and subsequently augmented by a militant utilitarianism which caused him to argue, like one of his main mentors at that time, the Russian critic and novelist Nikolai Chernyshevsky, in favour 
of an art that was devoted to social or scientific ends, frequently led him to distrust the imagination, and to disparage its works as a form of irresponsible play. Thus, in the polemical tract 'On the General Discontent, its Causes and Cures' (Om det allmänna missnöjet, dess orsaker och botemedel) of 1884, which he described in a letter to his publisher, Karl Otto Bonnier, as 'the key to all my writings' [IV, 35], he 'disowns part of his previous work as [that of a] "player" and draws 'the sharpest distinction between the pleasurable and the useful' [SS 16, 43]. Where, in the past, 'the writer was originally a player out to "amuse", his role is now to speak plainly, and his (Strindberg's) own writing, in which he assumes the challenging role of a 'teller of truths' (sanningssägaren) - is predicated upon a moral imperative. Thus, he insists that he would like to write 'brightly and beautifully', but that he may - or can - not since it is his duty to tell the truth, and then goes on to overturn the traditional hierarchy of 'skald', 'författare' and 'litteratör' (poet, author and journalist) that prevails within the late nineteenth-century Swedish literary institution in order to praise the latter because, unlike the two former, who beautify and play to the gallery, 'he is the one who, when he is honest, says the straight [lit. pure - ren] word at the right moment, avoiding every loophole' [SS 16, pp. 43, 50]. In 'On the General Discontent' it is 'the plain word' (det blanka ordet) that he prizes, 'the naked word of the newspapers [which], on the assumption that it is true, is greater than the embellished language of the imaginative writer' [SS 16,53 ], while in the brief essay 'On Realism' (Om realism) of 1882, he accepts the accusation of being a naturalist as 'an honorary title', and declares that he and his school of writers 'love nature' and 'because we hate the artificial, the heightened, we love to call each thing by its name' [SS 17, 196].

To call a spade a spade, in short. Nothing could be further from symbolism, at least as it is formulated by Mallarmé, for whom evocation, allusion, and suggestion supplant description in order that the poet may, as he expresses it in Crise de vers, 'deliver up that volatile scattering which we call the Spirit and institute an exact relationship between the images, and let there stand out from it a third aspect, bright and easily absorbed, offered to divination' (liberer... la dispersion volatile soit l'esprit... Instituer une relation entre les images exacte, et que s'en détache un tiers aspect fusible et clair présenté à la divination). ${ }^{5}$ Any such suggestion is anathema to Strindberg during the 1880s, however, as a celebrated formulation from his essay 'On Realism' makes plain:

The author of these opinions can, when he reads an old-fashioned poem about a rose and a butterfly, not see these abstract family notions; his eye suffers agonies before it can select the species. This image can thus not elucidate the symbol either, the inner, spiritual, 'the inconstancy of love', for where the sensation is vague the idea becomes woolly. [SS 17, 192-93] 
There is a suggestion of what a less diffuse, more scientifically precise, literature might mean in practice in the short story 'Above the Clouds' (Över molnen), from the collection Utopias in Reality (Utopier i verkligheten), which Strindberg wrote in Switzerland two years later during the period when he was most immediately under the influence of the Russian nihilist movement. Two writers, Aristide and Henri, meet by chance on the verandah of a hotel from where they survey the beauty of the landscape; both of them are ill and on the verge of literary as well as mortal extinction. After Aristide has sought to 'say something beautiful about the Alps in the form of a poetic simile in which the clouds enveloping the mountain are compared to a host of angels, he concedes that while his formulation may 'tease the imagination [it] offers no clear picture', thus leaving the way open for his comparison to take the idea further:

Good! But how do you imagine the people of tomorrow will compose their poetry about the Alps? Like this perhaps: 'Dent du Midi; your secondary stratum of lime mixed With Dolomite; is today covered with snow; for three millimetres of snow fell in the night and the Bise blew with a storm force eight; when the snow melts we shall be able to sow maize; and break up the earth in our vineyards for the second time' [SV 19, 135]. ${ }^{6}$

In his own practice, of course, Strindberg did not adopt this parodic extreme. But for as long as he sought to live up to this conception of naturalism, the language that he employed, at least ostensibly, assumed a kind of transparency, even if, in the major naturalist plays of the later 1880s, this proved to be a very much more complex issue than these urgently polemical statements suggest. It observation was one of the key words of the age, and the ideal author a combination of newspaper reporter (referent) and scientific vivisector, the paradigm of the modern writer was not, as has sometimes been claimed, the photographer, whose transparencies purported to reproduce the world exactly as it appeared to the observing eye, but, even now, a beholder who was sensitive to the elaborate patterning that might be discerned in the far broader canvas of what Strindberg defined, in his 1889 essay 'On Modern Drama and Modern Theatre', as 'the greater naturalism' [SS 17, 289].7 As Roland Barthes declares, in Camera Lucida, of the essentially deictic language of photography, in a photograph 'a pipe... is always and intractably a pipe'; but in even the most realistic theatre, physical Objects as part of the mise en scène (Hedda Gabler's pistols, for example, the Count's boots in Miss Julie, or the pipe that Osvald smokes in Ibsen's Ghosts) tend to assume an active role and conjure up, or evoke, what is not immediately tangible and visible in the physical reality of the scene. Framed and focused, such objects already share in what Clive Scott has called 'Baudelaire's surnaturalisme, a state of perception which intensifies the existence of things, makes them hyperbolically themselves.' 
Nevertheless, writing naturalistically ultimately poses irresolvable problems for Strindberg. Given the nakedness with which he displays both himself and those most intimately related to him as items in the literary market place, an acute moral dilemma is apparent in his conception of naturalism from the outset. As he remarks, in the celebrated foreword to his autobiographical fiction, The Son of a Servant (1886), 'One only knows one life, one's own' [SV $20,373]$, and this must therefore form the basis of any literature that makes a pretence of truth. But there is then a consequence. If he is not to be quite literally written out, and start repeating himself, with all the consequences which that will have for a readership continually in search of something new, the writer must accumulate the capital of fresh experience, which has then immediately to be reinvested in language. As the literary entrepreneur, Smartman, observes in Strindberg's savage late fictional analysis of the literary scene, and his own role in it, Black Banners (Svarta fanor, 1904): 'Better an unhappy marriage, however, than none at all. One goes through it and comes out with more experience than before, and experience is capital' [SS 41, 290]. But the kind of conspicuous consumption of private experience in which Strindberg engages in his writing is ultimately a form of self-consumption (the vampire finally feeds upon itself, as the late chamber play The Pelican (1907) suggests), and such 'collections of experienced material' (materialsamlingar av erfarenheter), as he calls them in The Son of a Servant [SV 20, 209], are accumulated not only at a cost to himself but with painful consequences for others. After all, as Smartman implies, one does not live alone, and the impulse behind the seemingly directionless period between 1892 and 1897, during which Strindberg wrote little or no imaginative literature, is not only to renew himself as a writer, but also, and fundamentally, a reaction against the mode of writing in which he has so recently indulged, not least the literary execution of his first wife in the autobiographical fiction A Madman's Defence (1887-88), a book which the poverty of his rapidly disintegrating second marriage to Frida Uhl now tempts him to publish during this apparently fallow literary period in his life. Torn between the naturalist code of speaking what he regards as the naked, if painful, truth and the deeply felt immorality of making public his own and other people's private lives, he now experiences how 'the increased distaste which he had for some time felt for his profession as a writer developed into an abhorrence':

What an occupation (he writes, in 1898, in the autobiographical fiction The Cloister (Klostret)): to sit and flay one's fellow human beings and then offer their skins for sale and expect they should buy them, to be like the hunter who in his hunger hacks off his dog's tail, eats the flesh himself and gives the dog the bones, his own bones. To go about spying out people's secrets, to betray one's best friend's birthmark, use one's wife 
as a guinea pig, behave like a Croat, chop down, defile, burn and sell. Ugh! [SV 50, 95]

And when, after a six years' silence, Strindberg does eventually return to the theatre with a play (To Damascus I) that, however autobiographical, is manifestly the product of a new aesthetic, one fashioned, at least to some extent, in the environs of French symbolism, it is also worth noting that the writer's block, or 'creative bankruptcy', from which its protagonist, The Stranger (or The Unknown - Den Okände), describes himself as suffering, is due at least in part to the revulsion that he feels for his most recently published book, which turns out, of course, to be an account of his previous marriage. In short, it is only when Strindberg has evolved a new manner of writing that he is able to acknowledge a link between his guilt and his literary impotence, and thus once again enjoy what, in one of his letters to Axel Herrlin, he rather coyly calls 'the grace of being able to write for the theatre' [XII, 273; 2, 623].

Two activities stand out as playing a central role in the process of growth and artistic renewal that Strindberg underwent in the years between 1892 and 1897: his commitment to science and his painting. Indeed, the two provide an intriguing complement to each other, with the residue that accrued in his crucible sometimes resembling the form and colour of the scrapings that accumulated upon his palette. Likewise, in both practices, he enjoyed a freedom from the kind of moral dilemma that his naturalist aesthetic had imposed upon his writing. The chemical nomenclature and mathematical symbols on which he now relied to describe the natural world offered him a neutral language, one that encumbered him with no personal moral dilemmas, even though in time the formulae of such so-called 'chemical sonnets' as 'Types and Prototypes in Mineral Chemistry' (Typer och prototyper inom mineralkemien, 1898) or the Pythagorian speculations of 'Les Nombres cosmiques' (1898), would enable him to discern 'the master builder, conscious, calculating, measuring, writing his record of creation sometimes the right side up, easy to read, sometimes concealing his intentions in a back to front, or disguised, code' [SS 27, 560] in what appeared to him to be the remarkable consonance and order of, for example, the analogy between the atomic weight of metals and the distance of the planets from the sun or the composition of water and the distance of the sun from the earth [SS 27, 434-37]. Likewise, in his painting, where he was prepared to sanction the notions of play and pleasure that he found unacceptable in his writing, the aleatory practice that he describes in the essay 'The New Arts! Or the Role of Chance in Artistic Creation' (1894) gave Strindberg the freedom to explore his relationship to the natural world in a similarly open-ended way. In his painting he no longer seeks to create works of art that imitate, or transcribe, nature but rather to emulate what he understands to be nature's own artistic method and fashion 
new works in the way that he now assumes nature creates, with prodigal turns of fancy that have little to do with the rapidly emerging scientific orthodoxy of Darwinism. Moreover, if nature thus comprises a series of works of art, then again this supposes a creator whose handiwork, as Strindberg studies it in Paris in the miniature universe of the Jardin des Plantes, is to be discerned in what he calls nature's own visible pictures, those images or artefacts in the natural world that bear a striking resemblance to his own artistic caprices. Beginning with what he believed might be the random play of chance, by 1896 both his mathematical and chemical speculations and his painting have revealed a coherent design within the apparent chaos of the natural world, and hence, as part of that world, his own life too must have a presumably sensible and therefore moral meaning.

In short, the natural world that he portrays in his painting and in his scientific pamphlets emerges as a modernist work of art, to the external eye an apparent chaos but one in which the internal eye of the freely associating painter or speculator can discern a world of similarities, coincidence, and repetition. The universe now appears to Strindberg as a vast sign system whose creator has impressed his signature upon everything, from the markings on the throat of a moth to the tracings upon the surface of meteors and the shells of crabs, and from the atomic weight of metals and orbits of the planets to the circumstantial detail of his own life, which he was now once again prepared to try and recover in literature, beginning with the autobiographical fiction Inferno.

It is in seeking to define the language of this polysemic world, which he variously calls a 'cabbalistic cryptogram', a 'cipher', or a system of hieroglyphics, and where the visible seems always to bear a hidden relationship to an invisible world of correspondences or symbols, that an affinity between Strindberg and the French symbolists is most apparent. It is now that the streets of Paris and the landscape around Klam, near Grein in Austria, that he depicts in Inferno confirm Baudelaire's previously cited remark from L'Art romantique, namely that 'tout, forme, mouvement, nombre, couleur, parfum, dans le spirituel comme dans le naturel [est] significatif, réciproque, converse, correspondant'. ${ }^{10}$ Baudelaire's account of Paris as a forest of symbols in which forms are dissociated from their normal meanings and become threatening and strange anticipates the urban landscape that Strindberg explores in his novel, as it does the later surrealist fictions of André Breton or Louis Aragon. Likewise, his account of metaphor in the hands of 'les excellents poètes' as 'une adaptation mathématiquement exacte dans la circonstance actuelle, parce que ces comparaisons, ces métaphores et ces épithètes sont puisés dans l'inépuisable fonds de l'universelle analogie' ${ }^{11}$ is clearly in keeping with the link that Strindberg infers between science and the poetic imagination at this time, when the metaphorical thought processes that he had previously 
condemned as irresponsible play are now advanced as the basis of a scientific as well as a poetic method. The demon of analogy or, as Strindberg writes in his essay on the sunflower, 'Solrosen' (1896), the inclination 'to "see similarities everywhere"' (att "se likheter överallt" [SS 27, 358]), was now the basis on which the multiplicity and seeming disorder of the world that had eluded definition, even in the desperately seeking naturalism of By the Open Sea (I havsbandet, 1892), could be explained, and he sought urgently in the past for authorities, including variously Francis Bacon, Elias Fries, Bernardin de SaintPierre, Linnaeus, and, finally, Swedenborg, who might reinforce his method and confirm the existence of 'the infinite coherence in the apparently great disorder' (det oändliga sammanhanget i den skenbara stora oredan! [SS 27, 560]). 'Analogier $=$ korrespondenser $=$ harmonier', as he asserts at the start of 'Solrosen', thus equating Mallarmé and the symbolists with Swedenborg (correspondences) and Bernardin de Saint-Pierre (harmonies), in his search for a language that could sustain a literature in which the concrete vigour of his earlier naturalism might be underwritten, or validated, by the ability of this language to suggest, even as it minutely describes the visible world, the existence of another dimension, an unseen reality that would permit him to write as fiercely and revealingly of himself and his contemporaries in, for example The Pelican or The Dance of Death (1900) as ever he had done in the past, in A Madman's Defence or The Father (1887). Indeed, in this respect he goes beyond Mallarmé, who had conceded, in Crise de vers, that 'the diversity of idioms on earth prevents anyone from uttering the words which otherwise would be, by a single impression, materially the truth itself (la diversité, sur terre, des idiomes empêche personne de proférer les mots qui, sinon se trouveraient, par une frappe unique, elle-même matériellement la vérité). ${ }^{12}$ For Strindberg, as for Talleyrand, whom he frequently quotes or paraphrases, the Babel-like confusion of this diversity generally suggested that 'La Parole a été donné à l'homme pour deguiser sa pensée' (man has been given language in order to conceal his thoughts), ${ }^{13}$ and he frequently argued that it was thus employed to sustain the individual in his illusions and society in maintaining the public lie, with one notable exception, namely his own words as he confides them to the silence of the white page on which he writes. Here even after the revaluation of all his values during the mid 1890s, Strindberg still felt it a calling and a duty to intervene with the author's time-honoured freedom in human lives and destinies ('I sometimes wish I had been a writer with the well-established right to engage in every facet of people's lives and fates, a calling and a duty', as he has one of his narrators express it, in 'The Quarantine Master's First Tale' (Karantänmästarns första berättelse [SV 50, 191]). But what now gave him this authority was, he believed, that relationship with the beyond, or Jenseits as he sometimes called it, into which he entered through his awareness of the 
symbolic dimension of language, a text which he was learning to decipher even in its most mundane manifestations.

Unlike Mallarmé, therefore, his ideal is not merely to suggest but still to name, or rather, as in (say) The Dance of Death, with its roots in his relationship with his sister, Anna, and her husband, Hugo von Philp, to do both at once. ${ }^{14}$ It is consequently here that the interest in Swedenborg that he shares with the symbolists also serves to distinguish Strindberg's practice from theirs. Swedenborg's correspondences may offer intimations of another world, but first and foremost they manifest themselves as real experiences in this one. What appealed so powerfully to Strindberg in Swedenborg, besides the notion of vastation that provided him, as Göran Stockenström has shown, with a kind of dramatic peripeteia around which to structure his later plays, ${ }^{15}$ was the circumstantial realistic detail of his visions, in which Strindberg recognized not only his own dreams but also his very own local habitation and name. As Gunnar Brandell observed, in Strindberg in Inferno, 'Nothing separates Strindberg from the symbolists so decisively as his stronger dependence on concrete reality and actual experience. The symbolists either created their symbols by an act of the imagination or else appropriated them from the fairy-tale world of romanticism. Strindberg found most of his symbols in exactly observed reality... A symbol is always something concrete that entails something abstract, but whereas the symbolists emphasize the abstract element, Strindberg stresses the concrete.'. ${ }^{16}$

Thus he never entirely abandons naturalism. The concrete data that he collects from 1896 to 1908 in The Occult Diary, which is both a repository of objets trouvés and an ongoing dictionary of symbols that is first explored in Inferno and subsequently deployed in To Damascus and the later plays and novels, remains the 'infinitely small detail' that, according to the Danish critic Georg Brandes, the realist or naturalist writer should use to 'reinforce the illusion of reality', although as Brandell, again, suggests, such detail now 'opens a window onto something beyond the real'. ${ }^{17}$ Or, as Strindberg himself was to remark, in Black Banners: 'Everyday life is full of mysticism, but you see so badly; and you must be a Naturalist in order to become a mystic. But it is not only a question of being able to spell, you have to "join it up", otherwise you can't read' [SS 41, 200].

Strindberg was himself a masterly reader of this kind, and nowhere more obviously than in the following brief passage from Inferno. Walking down a street in Meudon, where he has gone 'utan bestämd avsikt' (without any particular purpose) on a day trip from Paris, he catches sight of the statue of

... a Roman knight wearing iron grey armour, half buried in the ground... The knight is regarding the adjacent wall and guided by his gaze I am able to see an inscription in charcoal on its white-washed surface. The 
intertwined letters $\mathrm{F}$ and $\mathrm{S}$ lead me to think of the initials of my wife's name [Frida Strindberg]. She loves me still! A second later the thought of the chemical symbols for iron and sulphur $F e$ and $S$ suddenly flashes upon me and before my very eyes the secret of gold is revealed. [SV 37, 69]

But at this point one realizes that in exploring the concrete detail of everyday life in which the mundane residue of his private experience coheres with the detritus of the urban landscape, It is neither Mallarmé nor Swedenborg with whom the rapid play of Strindberg's symbolically associating imagination has most in common, but his near contemporary Freud, who, like him, was even then seeking to decipher the syntax and symbolism of the unconscious. That Strindberg had recourse to Swedenborg and an earlier form of dream interpretation in seeking to interpret these 'analogies = correspondences = harmonies' is understandable; for although he shared many points of reference with Freud (for example Die Philosophie der Mystik (1885) by Carl du Prel, whom Freud, in the 1914 edition of The Interpretation of Dreams, called that brilliant mystic' and 'one of the few authors for whose neglect in earlier editions of this book I should wish to express my regret'), he did not know Freud's work and, for all the sophistication of his own associational processes, he was not prepared to make the kind of symbolical interpretation that these multivalent texts continually invite. Thus here, for example, that the letters $F$ and $S$ should reveal the secret of a substance for which he had long been seeking, and which in chemical nomenclature shares the initial letters of his own authorial first name, $\mathrm{Au}$, is a correspondence that even Strindberg appears not to have noticed. Perhaps that was just as well! ${ }^{19}$ 